\title{
Effect of arsenic on photosynthesis, growth and yield of five widely cultivated rice (Oryza sativa $\mathrm{L}$ ) varieties in Bangladesh
}

M. Azizur Rahman ${ }^{1}$; H. Hasegawa ${ }^{1}$; M. Mahfuzur Rahman ${ }^{2}$; M. Nazrul Islam² and M. A. Majid Miah ${ }^{3}$;

A. $\operatorname{Tasmin}^{4}$

${ }^{1}$ Graduate School of Natural Science \& Technology, Kanazawa University, Kakuma, Kanazawa 9201192, Japan; ${ }^{2}$ Department of Botany, Jahangirnagar University, Savar, Dhaka-1342, Bangladesh;

${ }^{3}$ Bangladesh Rice Research Institute (BRRI), Division of Soil Science, Gazipur, Bangladesh. ${ }^{4}$ Institute of Education and Research (IER), University of Dhaka, Dhaka-1000, Bangladesh

*Corresponding author

Tel/Fax +81-76-234-4792

E-mail: rahmanmazizur@gmail.com; aziz_ju@yahoo.com

\section{Abstract:}


A glass house experiment was conducted to investigate the effect of soil arsenic on photosynthetic pigments, Chlorophyll-a and -b, and their correlations with rice yield and growth. The experiment was designed with three replications of six arsenic treatments viz. control, 10, 20, 30, 60, $90 \mathrm{mg}$ of $\mathrm{As} \mathrm{kg}^{-1}$ soil. Arsenic concentration in initial soil, to which the above mentioned concentrations of arsenic were added, was $6.44 \pm 0.24 \mathrm{mg} \mathrm{kg}^{-1}$. Both chlorophyll-a and -b contents in rice leaf decreased significantly $(p<0.05)$ with the increase of soil arsenic concentrations. No rice plant survived up to maturity stage in soil treated with 60 and $90 \mathrm{mg}$ of $\mathrm{As} \mathrm{kg}^{-1}$. The highest chlorophyll-a and -b contents were observed in control treatment (2.62 \pm 0.24 and $2.07 \pm 0.14 \mathrm{mg} \mathrm{g}^{-1}$ were the average values of chlorophyll-a and -b, respectively of the five rice varieties) while $1.50 \pm 0.20$ and $1.04 \pm 0.08 \mathrm{mg} \mathrm{g}^{-1}$ (average of five rice varieties) of chlorophyll-a and -b, respectively were the lowest. The content of photosynthetic pigments in these five rice varieties did not differ significantly $(p>0.05)$ from each other in control treatment though they differed significantly $(p<0.05)$ from each other in $30 \mathrm{mg}$ of $\mathrm{As} \mathrm{kg}^{-1}$ soil treatment. Among the five rice varieties, chlorophyll content in BRRI dhan 35 was found to be mostly affected with the increase of soil arsenic concentration while BRRI hybrid dhan 1 was least affected. Well correlations were observed between chlorophyll content and rice growth and yield suggesting that arsenic toxicity affects the photosynthesis which ultimately results in the reduction of rice growth and yield.

Key words: Arsenic, Rice, Photosynthesis, Chlorophyll, Growth, Yield

\section{Introduction}


Arsenic is one of the toxic environmental pollutants which has recently attract attention because of its chronic and epidemic effects on human health through widespread water and crop contamination due to the natural release of this toxic element from aquifer rocks in Bangladesh (Fazal et a., 2001; Smith et al., 2000; Ahmed, 2000; Hopenhayn, 2006), West Bengal, India (Chakraborti and Das, 1997; Banerjee, 2000). Geogenic contamination of arsenic in aquifer rocks has also been reported in Thailand (Visoottiviseth et al., 2002), Vietnam, Inner Mongolia, Greece, Hungary, USA, Ghana, Chile, Argentina and Mexico (O’Neill, 1995; Smedley and Kinniburgh, 2002).

Bangladesh is one of the major rice growing countries. The people of Bangladesh are not only drink the arsenic contaminated groundwater but also irrigate their crops. About 33\% of total arable land of the country is under irrigation facilities (BBS, 1996). Irrigation is principally performed in dry season for Boro rice cultivation. In Bangladesh, a large number of shallow tubewell (STW) and deep tubewell (DTW) have been installed to irrigate about 4.3 million hectors of crop land which contributes to the food grain production of the country significantly (Rashid et al., 2004). Long term irrigation with arsenic contaminated groundwater is likely to increase its concentration in crops (Ullah et al., 1998; Imamul Huq et al., 2003). The agricultural soil of arsenic non-contaminated areas of Bangladesh contain 4.0 to $8.0 \mathrm{mg}$ of $\mathrm{As} \mathrm{kg}^{-1}$ while that irrigated with arsenic contaminated groundwater, contain up to $83 \mathrm{mg}$ of $\mathrm{As}^{-1}$ (Ullah et al., 1998). The maximum acceptable concentration of arsenic in agricultural soil is $20 \mathrm{mg} \mathrm{kg}^{-1}$ (Kabata-Pendias and Pendias, 1992).

At higher concentration, arsenic is toxic to most plants. It interferes with metabolic processes and inhibits plant growth and development through arsenic induced phytotoxicity (Marin et al., 1993). When plants are exposed to excess arsenic either in soil or in solution culture, they exhibits toxicity symptoms such as: inhibition of seed germination (Abedin et al., 2002a); decrease in plant height (Marin et al., 1992; Carbonell-Barrachina et al., 1995; Abedin et al., 2002b; Jahan et al., 2003); depress in tillering (Kang et al., 1996; Rahman et al., 2004); reduction in root growth (Abedin et al., 2002a); decrease in shoot growth (Cox et al., 1996); lower fruit and grain yield (Carbonell-Barrachina et al., 1995; Abedin et al., 2002b; Kang et al., 1996); and sometimes, leads to death (Marin et al., 
1992; Baker et al., 1976). However, little is known about the effect of arsenic on photosynthesis, the basis of plant bio-chemical system. As almost all of the above mentioned adverse physiological and agronomical effects of arsenic are related to the basic photochemical reaction in rice plants, the photosynthesis, it is important to measure the chlorophyll-a and -b, the major photosynthetic pigments, contents in rice leaf to justify their correlations with rice growth and yield. The present study was undertaken to evaluate the effects of soil arsenic concentrations on chlorophyll contents, growth and yield of five popular and widely cultivated Boro rice (Oryza sativa L.) varieties in Bangladesh.

\section{Materials and Methods}

Pot experiment was conducted in a glass house and the duration of the experiment was about $120 \mathrm{~d}$ from transplanting to harvest. The experimental area is situated in sub-tropical and humid region, characterized by high temperature, moderately high rainfall during the rainy season (April September) and low temperature during the dry season (October - March). Though the experiment was conducted in glass house, the environmental conditions inside the glass house were not controlled strictly throughout the experiment. We maintain the natural environmental conditions inside the glass house. We use the glass house only to protect the experiment from some unwanted disturbances. Therefore, the conditions inside the glass house did not differ from that of out side. Thus, the environmental conditions of the experimental area represent the glass house conditions as well, which are shown in Table 1.

\section{Soil and pot preparation}

Soil was collected from Bangladesh Rice Research Institute’s (BRRI) rice field at a depth of 0-15 cm and treated with five different concentrations of arsenic viz. 10, 20, 30, 60, $90 \mathrm{mg} \mathrm{kg}^{-1}$. One control treatment was maintained to compare the results. The soil was sun dried for $7 \mathrm{~d}$ and massive aggregates were broken by gentle crushing with a hammer. The unwanted materials such as dry roots, 
grasses, stones were removed and the soil was mixed thoroughly. The physicochemical properties of this soil are presented in Table 2. Six kg of soil was taken in each of a series of eight litter volumetric plastic pots. Plastic pots, used in this experiment, had no pore in the bottom to protect leaching of water soluble arsenic from the soil solution. Plastic pots were washed by tap water and sun dried before taking soil into them. The experiment was arranged following the factorial RCBD with three replications for each treatment.

\section{Arsenic treatment and fertilizer application}

Arsenic was treated on soil basis and sodium arsenate $\left(\mathrm{Na}_{2} \mathrm{HAsO}_{4} \cdot 7 \mathrm{H}_{2} \mathrm{O}\right)$ was used as the source of arsenic. After application of arsenic in soil as water solution, the soil was left for $2 \mathrm{~d}$ without irrigation. After that, about 4.5 litter of tap water was irrigated in each of the pots to make the dry soil clay, suitable for rice seedling transplantation. About 5-6 cm water level was maintained above the clay. The tap water, used for irrigation, contained $0.001 \mathrm{mg} \mathrm{l}^{-1}$ of arsenic which is much less then the permissible limit for drinking water recommended by Bangladesh government $\left(0.05 \mathrm{mg} \mathrm{l}^{-1}\right.$ is the safe level of arsenic in drinking water recommended by Bangladesh government). Therefore, addition of arsenic to the soil from irrigation water was negligible.

To support plant growth, each pot received an equal amount of urea, tri-sodium phosphate (TSP), murate of potash (MP), and gypsum fertilizer at the rate of 1.3, 0.5, 0.6 and $0.4 \mathrm{~g} \mathrm{pot}^{-1}$ for nitrogen, phosphorus, potassium and sulfur, respectively. The first spilt (one hired of the dose) of urea and full doses of all other fertilizers were incorporated into the soil by hand before $2 \mathrm{~d}$ of transplantation. The second and third splits of urea were applied after $35 \mathrm{~d}$ (maximum tillering stage) and $75 \mathrm{~d}$ (panicle initiation stage) of transplantation, respectively.

\section{Selection of rice varieties and seedling transplantation}

Five high yielding, popular and widely cultivated Boro rice varieties (Oryza sativa L.) of arsenic contaminated area of Bangladesh, namely BRRI dhan 28, BRRI dhan 29, BRRI dhan 35, BRRI dhan 
36 and BRRI hybrid dhan 1, were selected for the experiment. Seedlings of $45 \mathrm{~d}$ old were uprooted carefully from seedbed and transplanted on the same day in flooded condition. Four seedlings, six inches apart from each other, were transplanted in each pot. The seedlings, which died within $6 \mathrm{~d}$ of transplantation, were discarded and new seedlings were replaced.

\section{Intercultural operation and harvest}

Two insecticides, namely Basudin (solid) and Malathion (liquid), were applied in the soil to kill insects and aphids attacked the rice plants. After transplantation, 5-6 cm of water from the soil level was maintained in each pot throughout the growth period irrigating tap water. The pots were infested with some common weeds which were uprooted by hand carefully. Irrigation was stopped before $10 \mathrm{~d}$ of harvest. The rice plants were harvested at their maturity stage (120 d after transplantation). Rice plants were cut at $4 \mathrm{~cm}$ above the soil. Then the collected rice from each pot was properly tagged and sun dried for $3 \mathrm{~d}$.

\section{Determination of photosynthetic pigments}

Chlorophyll-a and -b contents in rice leaf were determined at the flowering stage because photosynthetic rate at this stage is positively correlated with grain yield (Cook and Evans, 1983). The chlorophyll-a and -b were determined spectrophotometrically. Leaf was cut into small pieces leaving away the midribs, mixed thoroughly and $0.25 \mathrm{~g}$ of the leaf was taken into a mortar to grind them finely by pastel with $25 \mathrm{ml}$ of $80 \%$ cold acetone for $2 \mathrm{~min}$. Small amount of $\mathrm{Na}_{2} \mathrm{CO}_{3}$ was added to the leaf before grinding to check degradation of pigments during grinding. The homogenate was filtered through filter paper (Whatman no.1) and was made a volume of $25 \mathrm{ml}$ with $80 \%$ cold acetone. The optical density of each solution was measured at 663 and $645 \mathrm{~m} \mu$ against $80 \%$ acetone blank in $1.5 \mathrm{~cm}$ cell. Specific absorption co-efficient method of Mckinney (1990) and the Equation of Machlachalan and Zalik (1963) were used to calculate the amount of chlorophyll-a and -b. 


\section{Determination of plant growth and yield}

Plant height, number of tiller and shoot biomass were recorded for the measurement of plant growth. Plant height was recorded after $80 \mathrm{~d}$ of transplantation using meter scale. The number of tiller in each pot was counted at the maximum tillering stage. The shoot biomass pot $^{-1}$ (defined as the remaining aboveground portion of the rice plant after the spikelets have been removed) was measured after oven drying at $65^{\circ} \mathrm{C}$ for $3 \mathrm{~d}$. Grain yield and number of panicle pot ${ }^{-1}$ were recorded after harvest. Filled grains (true spikelets) were separated from the panicle by hand and counted for each panicle separately. Grain yield pot ${ }^{-1}$ was calculated as [ $\{(100$-moisture content of the sample $) \times$ fresh grain weight $\} \div 86$ ] to convert the sample to $14 \%$ moisture content.

\section{Determination of soil arsenic}

The soil was digested with concentrate nitric acid and perchloric acid. After sundry for $7 \mathrm{~d}$, the soil was dried in closed oven at $65^{\circ} \mathrm{C}$ for $48 \mathrm{~h}$. In a dry clean digestion tube, $5 \mathrm{ml}$ of $65 \%$ nitric acid was added to $0.5 \mathrm{~g}$ of soil. The mixture was allowed to stand over night under fume shade. In the following day, the digestion tubes were placed on heating block and the temperature was raised to $60^{\circ} \mathrm{C}$. After heating for $1 \mathrm{~h}$ at this temperature, the tubes were picked up from the heating block and allowed to be cool. Then $2 \mathrm{ml}$ of concentrated perchloric acid and $3 \mathrm{ml}$ of $\mathrm{H}_{2} \mathrm{SO}_{4}$ was added and the tubes were heated again at $160^{\circ} \mathrm{C}$. Heating was stopped when the dense white fumes of perchloric acid occurred. The digests were cooled, diluted to $25 \mathrm{ml}$ with distilled deionized water and filtered into plastic bottles through filter paper (Whatman, No.1). Total arsenic was determined by hydride generation atomic absorption spectrophotometer (HG-AAS, PerkinElmer, Germany) using matrix-malched standards (Welsch, et al., 1990). All glassware and plastic bottles were washed by distilled deionized water and dried before use. 
In each analytical batch at least two reagent blanks, one spike and three duplicate samples were included in the acid digests to asses the accuracy of the analytical method. The accuracy of the method, according to the spike, was $92.3 \%$.

\section{Statistical analysis}

The experimental data were statistically analyzed for Least Significant Difference (LSD) at 5\% level by IRRISTAT 4.0 for windows (developed by the Biometrics unit, IRRI, Philippines). Correlation coefficient (r) was calculated by SPSS 10.0 for windows.

\section{Results and Discussions:}

\section{Effect of arsenic on chlorophyll content in rice leaf}

Photosynthesis is the most important biochemical event on earth. It serves as the world's largest solar battery. Photosynthesis converts massive amount of sunlight into electrical and then chemical energy (Hall and Rao, 1999). The most important photosynthetic pigment is chloroplast consists of two types of chlorophylls, chlorophyll-a and chlorophyll-b. Chemically they differ from each other and absorb light of different wavelength to perform photosynthesis. The single leaf net photosynthetic rate (SLPR) of rice plant is affected by stomatal conductance, leaf nitrogen content, specific leaf weight and chlorophyll content (Peng, 2000). The effect of arsenic, one of the fatal phytotoxic tress elements, on chlorophyll content in rice leaf was studied and observed that soil arsenic concentrations show negative correlations with the chlorophyll-a $\left(R^{2}=0.83\right)$ and chlorophyll-b $\left(R^{2}=0.75\right)$ contents in rice leaf (Figure 1). The experiment was conducted with five rice varieties and both chlorophyll-a and -b contents in rice leaf decreased with the increase of soil arsenic concentrations for all varieties (Table 3). Increased arsenic concentrations caused an alternation of the chloroplast shape, manifested in its rounding and shortening of the longitudinal axis of plant cell. Other manifestations are concaving

membrane, bending and partial destruction as well as changes in the accumulation and flow of 
assimilates which results in the decrease of chlorophyll content in rice leaf (Miteva and Merakchiyska, 2002).

The mean chlorophyll content in leaf of five rice varieties did not affected significantly up to $10 \mathrm{mg}$ of As $\mathrm{kg}^{-1}$ soil treatment. The mean chlorophyll-a contents in leaf of five rice varieties were $2.62 \pm 0.24$, 2.55 $\pm 0.47,2.29 \pm 0.31$ and $1.50 \pm 0.10 \mathrm{mg} \mathrm{g}^{-1}$ in control, 10, 20 and $30 \mathrm{mg}$ of $\mathrm{As} \mathrm{kg}^{-1}$ soil treatments, respectively while chlorophyll-b contents were $2.07 \pm 0.14,1.94 \pm 0.28,1.59 \pm 0.34$ and $1.04 \pm 0.08 \mathrm{mg} \mathrm{g}$ ${ }^{1}$, respectively. No data were found in 60 and $90 \mathrm{mg}$ of $\mathrm{As} \mathrm{kg}^{-1}$ soil treatments because all plants died at panicle initiation stage at these arsenic treatments. However, the chlorophyll content in five rice varieties did not differ significantly $(p>0.05)$ from each other in control treatment though they differed significantly $(p<0.05)$ from each other in $30 \mathrm{mg}$ of $\mathrm{As} \mathrm{kg}^{-1}$ soil treatment (Table 3). Among the five rice varieties, chlorophyll content in BRRI dhan 35 was found to be mostly affected with the increase of soil arsenic concentration while BRRI hybrid dhan 1 was least affected.

Although there is no report on the effect of arsenic on chlorophyll content in rice plant, Miteva and Merakchiyska (2002) reported that arsenic concentrations of $25 \mathrm{mg} \mathrm{kg}^{-1}$ soil did not have negative effect on the photosynthetic process in bean plants (Phaseolus vulgaris L.), while the higher doses (50 and $100 \mathrm{mg}$ of $\mathrm{As} \mathrm{kg}^{-1}$ soil) inhibit the photosynthesis by 42 and 32\%, respectively.

\section{Effect of soil arsenic on rice growth and its correlation with chlorophyll content}

Tiller numbers, plant height and shoot biomass production of rice plant were recorded to determine the effect of soil arsenic concentrations on rice growth and its correlation with chlorophyll content. The

results are presented in Figure 2. The highest number of tiller $\left(15.51 \pm 1.00\right.$ pot $\left.^{-1}\right)$ was observed in BRRI hybrid dhan 1 at control arsenic treatment followed by $12.34 \pm 1.50,10.24 \pm 0.69,9.14 \pm 1.02$ and 8.43 \pm 1.02 in BRRI dhan 29, BRRI dhan 35, BRRI dhan 28 and BRRI dhan 36, respectively. On the other hand, the lowest number of tiller (4.01 \pm 2.00$)$ was observed in BRRI dhan 36 at $30 \mathrm{mg}$ of $\mathrm{As} \mathrm{kg}^{-1}$ soil treatment (Figure 2B). Plant height and shoot biomass production were also decreased drastically with the increase of soil arsenic concentrations (Figure 2A and 2C). Certainly, the reduction of rice 
plant growth, in terms of tillering, plant height and shoot biomass production, was the ultimate result of arsenic phytotoxicity at high soil arsenic concentrations (Jahan et al., 2003; Rahman et al., 2004; Xie and Huang, 1998) though the phytotoxicity at lower soil arsenic concentrations was not significant. At low soil arsenic concentration, displacement of soil phosphate by arsenate increased the availability of phosphate to the plant, which results in the increase of plant growth (Duel and Swoboda, 1972; Jacobs et al., 1970). Thus, Kabata-Pendias and Pendias (1992) recommended the safe level of arsenic in agricultural soil as $20 \mathrm{mg} \mathrm{As} \mathrm{kg}^{-1}$.

Although plant height is not directly influenced by photosynthesis rather then soil nutrients and some phytohormons, tillering or panicle formation as well as shoot biomass production was well correlated with the content of photosynthetic pigments in leaves $\left(R^{2}=0.88\right.$ and 0.95 for tillering or panicle formation and shoot biomass production, respectively) (Figure 4A, 4B). Nitrogen is the core component of chlorophyll molecule and thus, its content in leaf is directly correlated with chlorophyll content. Higher soil arsenic concentrations decrease the nitrogen content in garden pea (Paivoke, 1983) and silver bet (Merry et al., 1986). Thus, it is expected that the higher soil arsenic concentrations may also decrease nitrogen content in rice plant which may also cause the decrease of chlorophyll content. The results of the present experiment reveal that higher soil arsenic concentrations decrease the chlorophyll content and there by, lower the photosynthesis rate, because the net photosynthetic rate of rice is largely affected by leaf nitrogen content and specific leaf weight (Peng, 2000). The significant correlation between chlorophyll content and growth parameters of rice plant is in agreement with the above discussion.

It is also evident from the present experiment that among the different Bangladeshi rice varieties, nonhybrid varieties are highly affected in terms of growth and photosynthesis compared to those of hybrid varieties, though the mechanism is not clearly understood.

\section{Effect of soil arsenic on rice yield and its correlation with chlorophyll content}


Rice yield was measured on the basis of panicle number, filled grain production and weight of total grain. Results imply that increasing soil arsenic concentrations drastically reduces rice yield in all varieties. Number of panicle was found to be decreased significantly $(p<0.05)$ with the increase of soil arsenic concentrations as well (Figure 3). True (filled) grain production was also found to be decreased significantly $(p<0.05)$. In the present experiment it was observed that the number of panicle, filled grain and grin yield in control treatment were $12 \pm 1.0,101.47 \pm 3.7$ and $42.0 \pm 0.8$, respectively for BRRI hybrid dhan 1 while they were $7.12 \pm 1.05,52.54 \pm 1.64$ and $11.24 \pm 1.75$ for BRRI dhan 36; 8.54 $\pm 1.51,77.41 \pm 2.04$ and $13.90 \pm 90$ for BRRI dhan 35; 9.42 $\pm 1.55,83.32 \pm 4.01$ and 15.78 \pm 1.03 for BRRI dhan 29; 7.21 $\pm 1.02,54.42 \pm 1.83$ and $10.24 \pm 1.68$ for BRRI dhan 28, respectively. Montenegro and Mejia (2001) reported the reduction of rice yield by $10 \%$ with the increase of arsenic content in irrigation water.

The chlorophyll content in rice leaf and yield components (such as panicle formation, filled grain production and rice yield) were highly correlated $\left(R^{2}=0.88,0.95,0.84\right.$ for panicle formation, grain production and rice yield, respectively) (Figure 4B, 4C and 4D). The higher plants such as rice, maize, wheat, mosses, ferns and forest trees use the green pigment chlorophyll-a to run the photochemistry of photosynthesis and produce carbohydrate (Hall and Rao, 1999). Thus, the chlorophyll-a content is directly correlated with the carbohydrate production. Rice stores carbohydrate in grain. Therefore, the high negative correlation between chlorophyll content in leaf and rice yield might be the result of reduced photosynthetic rate due to arsenic toxicity.

\section{Conclusion}

Phytotoxicity of arsenic to rice (Oryza sativa L.) has been widely concerned because of large scale use of arsenic contaminated groundwater for irrigation in paddy field in Bangladesh and West Bengal, India. On the basis of well correlations between chlorophyll content and growth and yield of rice, it may conclude that the reduction of growth and yield of rice is the results of reduced chlorophyll 
content in rice leaf due to arsenic toxicity. To better understand the biochemical basis of the reduction of chlorophyll content in rice leaf, further investigation is needed.

\section{Acknowledgement}

The authors are grateful to the Bangladesh Rice Research Institute (BRRI) authority for their full cooperation and necessary facilities in conducting this experiment. The first author is thankful to the Ministry of Science, Information and Communication Technology, Government of the People's Republic of Bangladesh, for awarding the NSICT fellowship for this research work.

\section{References}

Abedin, M. J., Meharg, A. A., 2002a. Relative toxicity of arsenite and arsenate on germination and early seedling growth of rice (Oryza sativa L.). Plant and Soil. 243, 57-66.

Abedin, M. J., Cottep-Howells, J., Meharg, A. A., 2002b. Arsenic uptake and accumulation in rice (Oryza sativa L.) irrigated with contaminated water. Plant and Soil. 240, 311-319.

Ahmed, K. M., 2000. Groundwater arsenic contamination in Bangladesh: An overview. In: Bhattacharya, P. and Welch, A. H. (Eds.). Arsenic in groundwater of sedimentary aquifers. $31^{\text {st }}$ International geological congress, Rio de Janerio, Brazil. pp. 3-11.

Baker, S., Barrentine, W. L., Bowmaan, D. H., Haawthorne, W. L., Pettiet, J. V., 1976. Crop response and arsenic uptake following soil incorporation of MSMA. Weed Sci. 24, 322-326.

Banerjee, D. M., 2000. Some comments on the source of arsenic in the Bengal Deltaic sediments. In: Bhattacharya, P. and Welch, A. H. (Eds.). Arsenic in groundwater of sedimentary aquifers. $31^{\text {st }}$ International geological congress, Rio de Janerio, Brazil. pp. 15-17.

Bangladesh Bureau of Statistics (BBS), 1996. In: Statistical year book of Bangladesh, Bangladesh bureau of statistics, statistics division, ministry of planning, peoples republic of Bangladesh. p. 10. 
Carbonell-Barrachina, A. A., Burlo-Carbonell, F., Mataix-Beneyto, J., 1995. Arsenic uptake, distribution and accumulation in tomato plants: effect of arsenic on plant growth and yield. J. plant Nutri. 18, 1237-1250.

Chakraborti, A. K. and Das, D. K., 1997. Arsenic pollution and its environmental significance. Interacad. 1, 262-276.

Cook, M. G. and Evans, L. T., 1983. Some physiological aspects of the domestication and improvement of rice (Oryza spp.). Field Crops Res. 6, 219-238

Cox, M. S., Bell, P. F., Kovar, J. L., 1996. Different tolerance of canola to arsenic when grown hydroponically or in soil. J. Plant Nutri. 19, 1599-1610.

Duel, L. E. and Swoboda, A. R., 1972. Arsenic toxicity to cotton and soybeans. J. Environ. Qual. 1, $317-320$

Fazal, M. A., Kawachi, T., Ichio, E., 2001. Validity of the latest research findings on causes of groundwater arsenic contamination in Bangladesh. Water International. 26(2), 380-389.

Hall, D. O. and Rao, K. K., 1999. Photosynthesis. $6^{\text {th }}$ Edition, Cambridge University Press, Cambridge, UK. ISBN 0-521-644976. p. 214.

Hopenhayn C., 2006. Arsenic in drinking water: Impact on human health. Elements. 2, 103-107.

Imamul Huq, S. M., Rahman, A., Sultana, S., Naidu, R., 2003. Extent and severity of arsenic contamination in soils of Bangladesh. In: F. Ahmed, M. A. and Ali, Z. A., (Eds.). Fate of arsenic in the environment. BUET-UNU Int. Symp. Dhaka, Bangladesh. pp. 69-84.

Jacobs, L. W., Keeny, D. R., Walsh, L. M., 1970. Arsenic residue toxicity to vegetables crops grown on plain field sand. Agron. J. 62, 588-591

Jahan, I., Hoque, S., Ullah, S. M., Kibria, M. G., 2003. Effects of arsenic on some growth parameters of rice plant. Dhaka Univ. J. Biol. Sci. 12, 71- 77.

Kabata-Pendias, A. and Pendias, H., 1992. Trace element in soil and plants. CRC, $2^{\text {nd }}$ Edition. London, UK. 
Kang, L. J., Li, X. D., Liu, J. H., Zhang, X. Y., 1996. The effect of arsenic on the growth of rice and residues in a loam paddy soil. J. Jilin Agric. Univ. 18, 58-61.

Machlachalan, S. and Zalik, S., 1963. Plastid structure, chlorophyll concentration and free amino acid composition of a chlorophyll mutant of barley. Can. J. Bot. 41, 1053-1062.

Marin, A. R., Masscheleyn, P. H., Patrick, W. H. Jr., 1992. The influence of chemical form and concentration of arsenic on rice growth and tissue arsenic concentration. Plant and Soil. 139, 175-183.

Marin, A. R., Pezeshki, S. R., Masscheleyn, P. H., Choi, H. S., 1993. Effect of dimethylarsinic acid (DMAA) on growth, tissue arsenic and photosynthesis of rice plants. J. Plant Nutr. 16, 865880.

Mckinney, G., 1990. Criteria for purity of chlorophyll preparation. J. Biol. Chem. 132, 91-107

Merry, R. H., Tiller, K. G., Altson, A. M., 1986. The effects of contamination of soil with copper, lead and arsenic on the growth and composition of plants, I. effects of season, genotype, soil temperature and fertilizers. Plant and Soil. 91, 115-128.

Miteva, E. and Merakchiyska, M., 2002. Response of chloroplasts and photosynthetic mechanism of bean plants to excess arsenic in soil. Bulg. J. Agric. Sci. 8, 151-156.

Montenegro, O. and Mejia, L., 2001. Contamination of rice (Oryza sativa L.) with cadmium and arsenic by irrigation with water of Bogota river in rice soils of the lower basin. Suelos Ecuatoriales. 31, 26-31.

O’Neill, P., 1995. Arsenic, In Heavy Metals in Soils. Alloway, B. J. (Ed.). pp. 105-121.

Paivoke, A., 1983. The term effect of lead and arsenate on the growth and development, chlorophyll content and nitrogen fixation of the garden pea. Annals-Botanici-Fennici. 20, 297-306.

Peng, S., 2000. Single-leaf and canopy photosynthesis of rice. In: Sheehy, et al., (Eds.). Redesigning rice photosynthesis to increase yield. Elsevier, Amsterdam. pp. 213-228.

Rahman, M. A., Rahman, M. M., Miah, M. A. M., Khaled, H. M., 2004. Influence of soil arsenic concentrations in rice (Oryza sativa L.). J. Sub-trop. Agric. Res. Dev. 2, 24-31. 
Rashid, H. A., Nath, D. K., Hossain, M., Khan, M. U., Shah, A. L., Saleque, M. A., Rahman, M. S., Ghani, M. A., 2004. Variation of arsenic content in groundwater with depth and river distance: GIS mapping. In: Latif Shah, et al., (Eds.). Arsenic in the food chain: assessment of arsenic in the water-soil-crop systems. BRRI, Gazipur, Bangladesh. pp. 53-71.

Smedley, P. L. and Kinniburgh, D. G., 2002. A review of the source, behaviour and distribution of arsenic in natural waters. Appl. Geochem. 17, 517-568.

Smith, A. H., Lingas, E.O., Rahman, M., 2000. Contamination of drinking water by arsenic in Bangladesh: a public health emergency. Bull. Of the World Health Organization, 78 (9), 1093-1103.

Ullah, S. M., 1998. Arsenic contamination of groundwater and irrigated soils of Bangladesh. In: International conference on arsenic pollution of groundwater in Bangladesh: causes, effects and remedies. DCH, Dhaka, Bangladesh. p. 133.

Visoottiviseth, P., Francesconi, K., Sridokchan, W., 2002. The potential of Thai indigenous plant species for the phytoremediation of arsenic contaminated land. Environ. Poll. 118, 453-461.

Welsch, E. P.,.Crock, J. G., Sanzolone, R., 1990. Trace-level determination of arsenic and selenium using continuous-flow hydride generation atomic absorption spectrophotometry (HG-AAS). In: Arbogast, B. F., (ed.). Quality assurance manual for the branch of geochemistry. OpenFile Rep. 90-0668. U.S. Geological Survey, Reston, VA. pp. 38-45.

Xie, Z. M. and Huang, C. Y., 1998. Control of arsenic toxicity in rice plants grown on arsenicpolluted paddy soil. Common. Soil Sci. Plant Anal. 29, 2471-247. 
Table 1: Environmental conditions of the experimental area during the experiment ${ }^{\text {a }}$

\begin{tabular}{|c|c|c|c|c|c|c|c|c|}
\hline \multirow{2}{*}{ Month } & \multicolumn{2}{|c|}{ Temperature $\left({ }^{\circ} \mathrm{C}\right)$} & \multicolumn{2}{|c|}{ Relative humidity (\%) } & \multirow{2}{*}{$\begin{array}{c}\text { Average } \\
\text { evaporation (mm) }\end{array}$} & \multirow{2}{*}{$\begin{array}{l}\text { Sunshine } \\
\left(\mathrm{hrs.d}^{-1}\right)\end{array}$} & \multirow{2}{*}{$\begin{array}{l}\text { Solar radiation } \\
\qquad\left(\mathrm{cal} \mathrm{cm}{ }^{-2}\right)\end{array}$} & \multirow{2}{*}{$\begin{array}{c}\text { Total rainfal } \\
(\mathrm{mm})\end{array}$} \\
\hline & Max. & Min. & 8:00 AM & 2:00 PM & & & & \\
\hline Jan.’04 & 24.00 & 12.70 & 80.50 & 53.10 & 2.00 & 5.90 & 261.60 & 8.00 \\
\hline Feb.’04 & 28.50 & 14.40 & 72.10 & 40.70 & 2.7 & 8.30 & 373.50 & 0.00 \\
\hline Mar.'04 & 32.80 & 21.60 & 75.30 & 44.90 & 4.60 & 7.60 & 403.60 & 7.40 \\
\hline Apr.'04 & 32.40 & 23.50 & 78.90 & 55.90 & 4.10 & 6.10 & 376.40 & 137.40 \\
\hline May’04 & 33.20 & 26.00 & 73.80 & 56.30 & 5.50 & 7.50 & 429.90 & 949.40 \\
\hline
\end{tabular}

a Bangladesh Rice Research Institute (BRRI), Gazipur, Bangladesh. Source: Plant Physiology Division, BRRI, Gazipur, Bangladesh. 
Table 2: Physicochemical properties of initial soil (before arsenic treatment, Mean $\pm \mathrm{SD}, n=3$ )

\begin{tabular}{ll}
\hline Soil properties & Average value \\
\hline \% Sand $(2-0.05 \mathrm{~mm})$ & $12.30 \pm 0.21$ \\
$\%$ Silt $(0.05-0.002 \mathrm{~mm})$ & $53.00 \pm 0.04$ \\
$\%$ Clay $(<0.002 \mathrm{~mm})$ & $34.70 \pm 0.03$ \\
Soil texture & Silty clay loam \\
Soil pH & $7.49 \pm 0.07$ \\
Total Nitrogen $(\%)$ & $0.15 \pm 0.03$ \\
Total Iron (\%) & $0.22 \pm 0.01$ \\
Total Manganese $\left(\mathrm{mg} \mathrm{kg}^{-1}\right)$ & $262.08 \pm 4.50$ \\
Total Arsenic (mg kg-1) & $6.44 \pm 0.24$ \\
Available Phosphorus $\left(\mathrm{mg} \mathrm{kg}^{-1}\right)$ & $4.30 \pm 0.03$ \\
\hline
\end{tabular}


Table 3: Effect of soil arsenic concentrations on chlorophyll (Chl-a + Chl-b) contents of five widely cultivated rice (Oryza sativa L.) varieties in Bangladesh ${ }^{\mathrm{a}}$

\begin{tabular}{|c|c|c|c|}
\hline \multirow{2}{*}{ Arsenic treatments $\left(\mathrm{mg} \mathrm{kg}^{-1}\right)$} & \multirow{2}{*}{ Rice varieties } & \multicolumn{2}{|c|}{ Chlorophyll content (mg g ${ }^{-1}$ ) } \\
\hline & & Chlorophyll-a & Chlorophyll-b \\
\hline \multirow{5}{*}{ Control } & BRRI dhan 28 & $2.70 \pm 0.02 \mathrm{a}$ & $2.09 \pm 0.04 a$ \\
\hline & BRRI dhan 29 & $2.56 \pm 0.04 \mathrm{a}$ & $2.10 \pm 0.14 \mathrm{a}$ \\
\hline & BRRI dhan 35 & $2.57 \pm 0.07 \mathrm{a}$ & $1.91 \pm 0.01 \mathrm{a}$ \\
\hline & BRRI dhan 36 & $2.66 \pm 0.08 \mathrm{a}$ & $2.22 \pm 0.07 a$ \\
\hline & BRRI hybrid dhan 1 & $2.62 \pm 0.02 \mathrm{a}$ & $2.06 \pm 0.12 \mathrm{a}$ \\
\hline \multirow{5}{*}{10} & BRRI dhan 28 & $2.65 \pm 0.10 \mathrm{a}$ & $2.00 \pm 0.01 \mathrm{a}$ \\
\hline & BRRI dhan 29 & $2.59 \pm 0.03 a$ & $2.19 \pm 0.04 a$ \\
\hline & BRRI dhan 35 & $2.36 \pm 0.07 b$ & $1.89 \pm 0.03 b$ \\
\hline & BRRI dhan 36 & $2.60 \pm 0.04 \mathrm{a}$ & $1.86 \pm 0.01 b$ \\
\hline & BRRI hybrid dhan 1 & $2.53 \pm 0.02 \mathrm{a}$ & $1.77 \pm 0.02 b$ \\
\hline \multirow{5}{*}{20} & BRRI dhan 28 & $2.03 \pm 0.07 \mathrm{~b}$ & $1.38 \pm 0.15 c$ \\
\hline & BRRI dhan 29 & $2.43 \pm 0.03 a$ & $1.67 \pm 0.02 \mathrm{a}$ \\
\hline & BRRI dhan 35 & $2.04 \pm 0.02 b$ & $1.51 \pm 0.04 \mathrm{~b}$ \\
\hline & BRRI dhan 36 & $2.46 \pm 0.10 \mathrm{a}$ & $1.70 \pm 0.03 \mathrm{a}$ \\
\hline & BRRI hybrid dhan 1 & $2.49 \pm 0.03 \mathrm{a}$ & $1.68 \pm 0.06 \mathrm{a}$ \\
\hline \multirow{5}{*}{30} & BRRI dhan 28 & $1.10 \pm 0.06 b$ & $0.79 \pm 0.02 \mathrm{c}$ \\
\hline & BRRI dhan 29 & $1.21 \pm 0.01 b$ & $0.90 \pm 0.06 b$ \\
\hline & BRRI dhan 35 & $0.87 \pm 0.01 \mathrm{c}$ & $0.47 \pm 0.02 d$ \\
\hline & BRRI dhan 36 & $2.05 \pm 0.04 \mathrm{a}$ & $1.55 \pm 0.01 \mathrm{a}$ \\
\hline & BRRI hybrid dhan 1 & $2.26 \pm 0.05 a$ & $1.48 \pm 0.00 \mathrm{a}$ \\
\hline
\end{tabular}

${ }^{\text {a }}$ Results are presented as mean \pm SD $(n=3)$. Data were statistically analyzed for Least Significant Difference (LSD) at 5\% level and different letters in a column indicates significant differences among the five rice varieties. No data were obtained in 60 and $90 \mathrm{mg}$ $\mathrm{kg}^{-1}$ soil arsenic treatments because, all plants died at these arsenic treatments. 

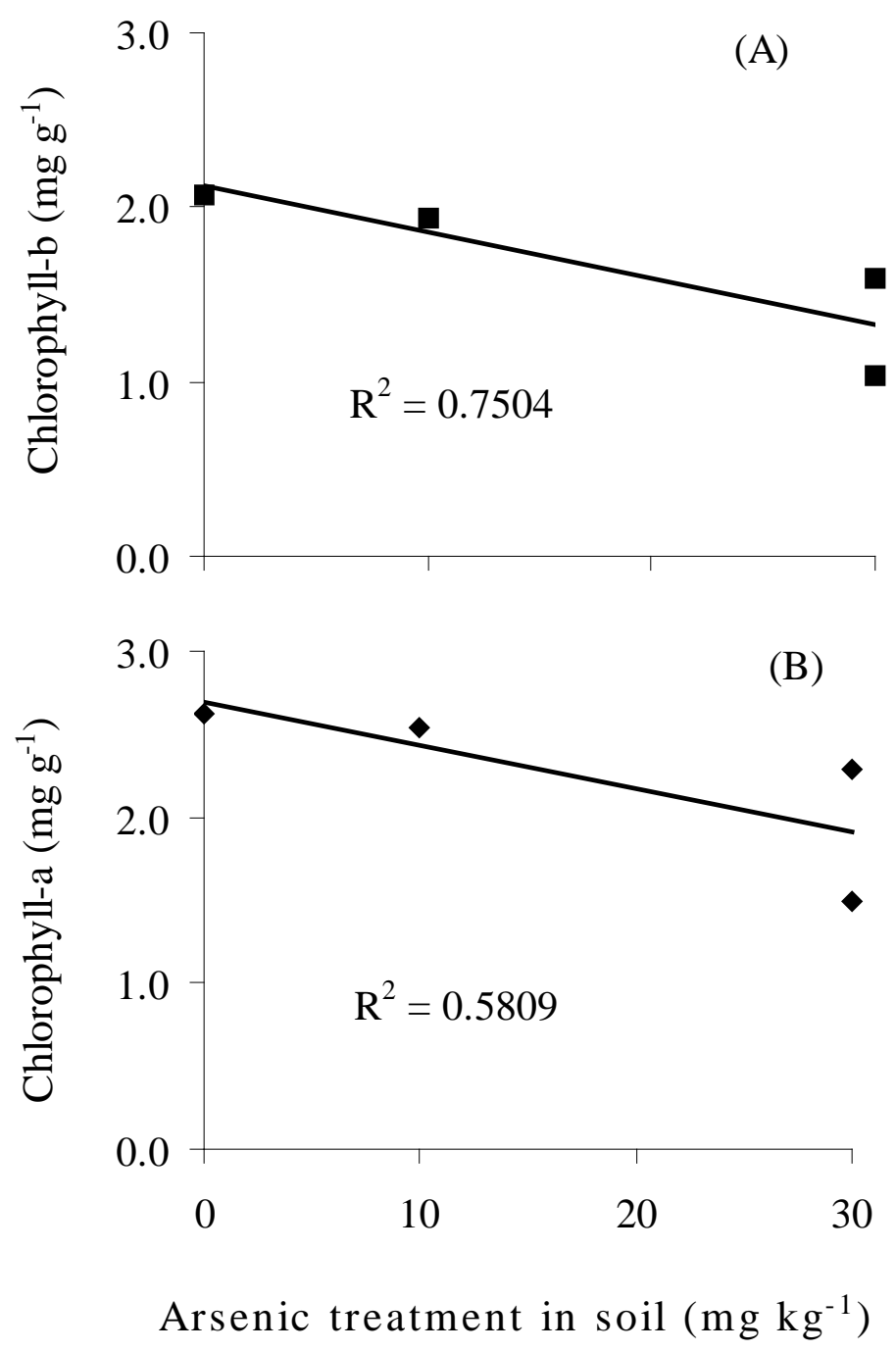

Fig 1: Correlation between soil arsenic concentrations and photosynthetic pigments in rice leaves, chlorophyll-b (A) and chlorophyll-a (B). The chlorophyll-a and -b content refer to the average value of the five rice verities. 

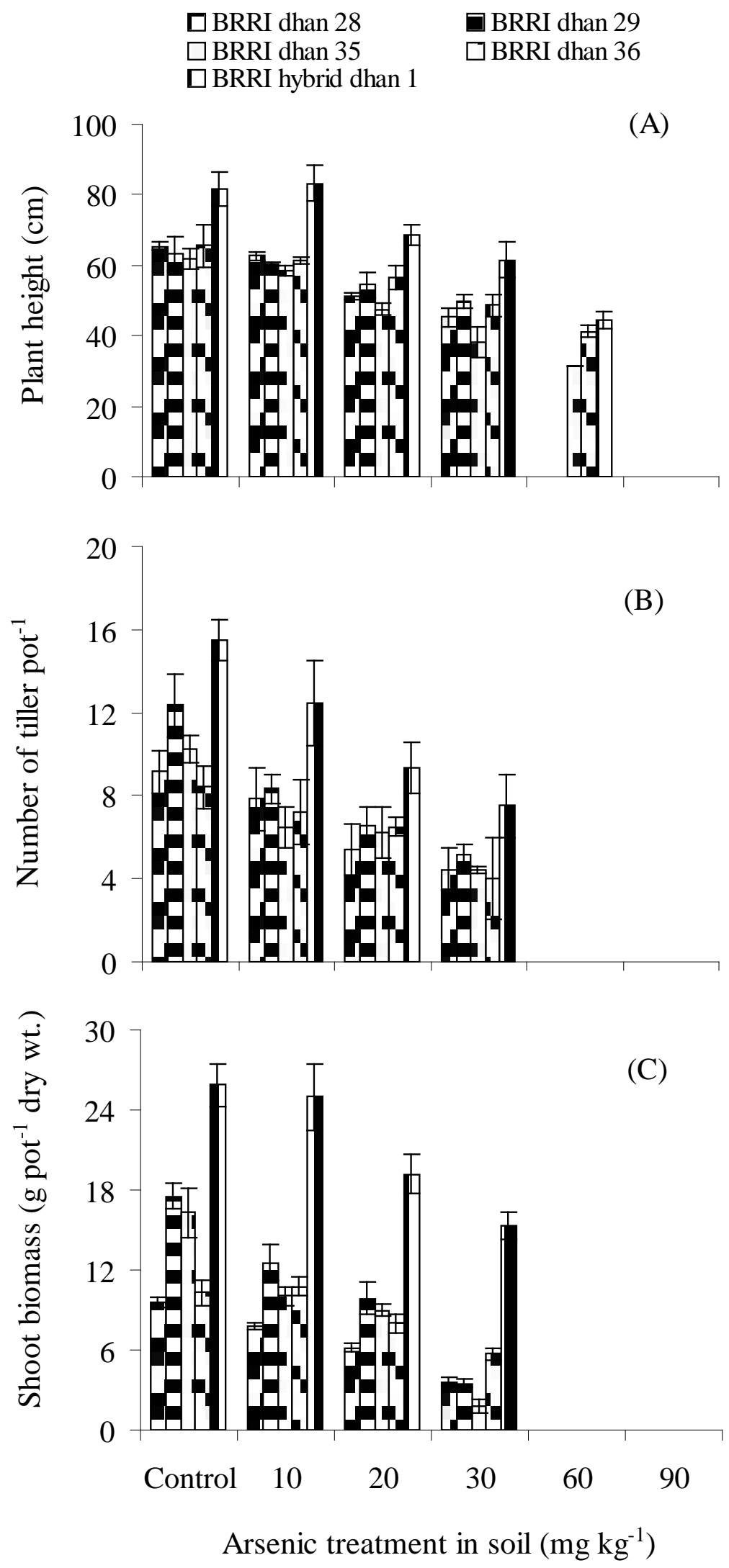

Fig 2: Effect of soil arsenic concentrations on growth of rice plant. Error bars represent \pm SD ( $n$ = 3). Plant height (A), tillering (B) and shoot biomass production (C). 

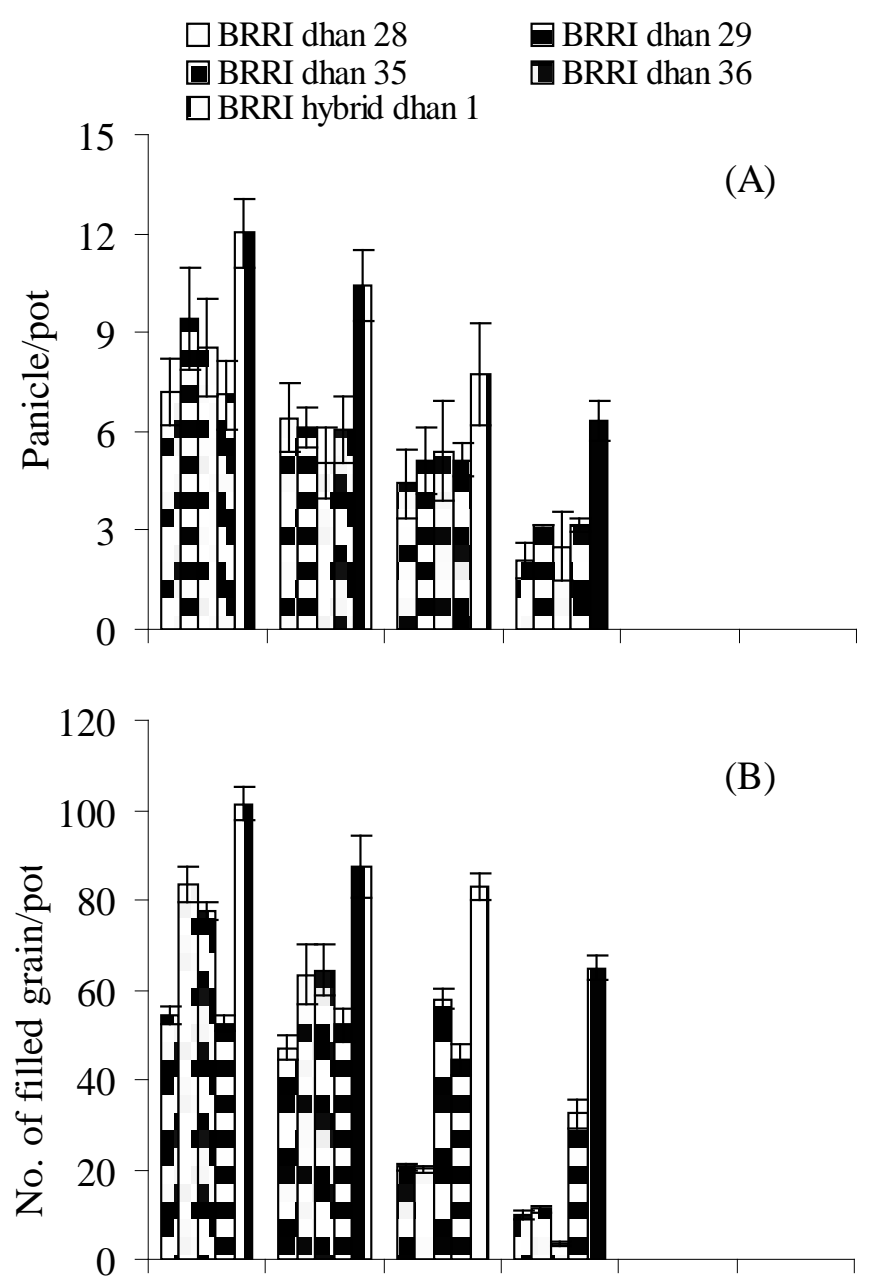

(B)

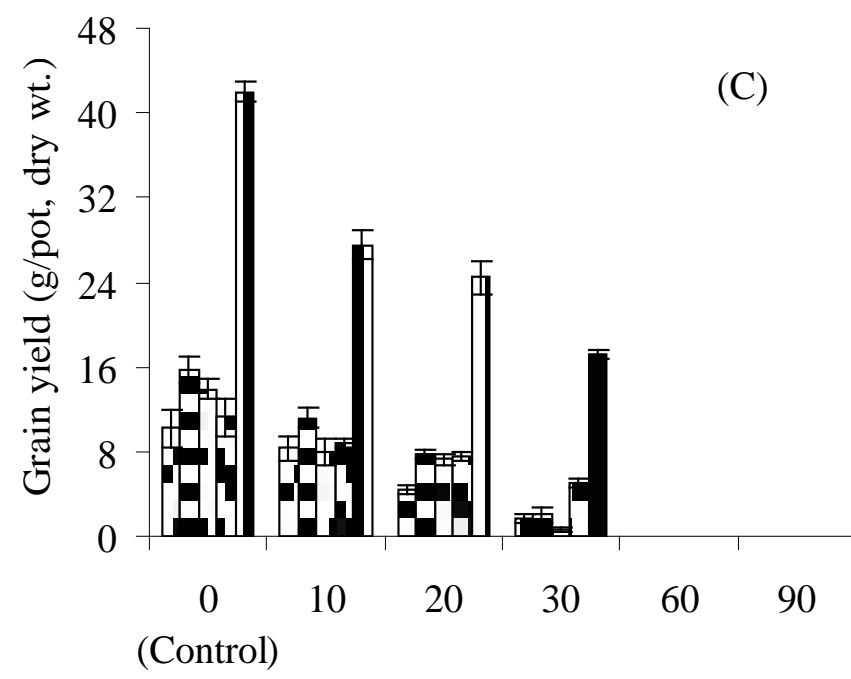

Added arsenic in soil (mg/kg)

Fig 3: Effect of soil arsenic concentrations on rice yield. Error bars represent \pm SD $(n=3)$. Panicle formation (A), filled grain formation (B) and grain yield (C). 

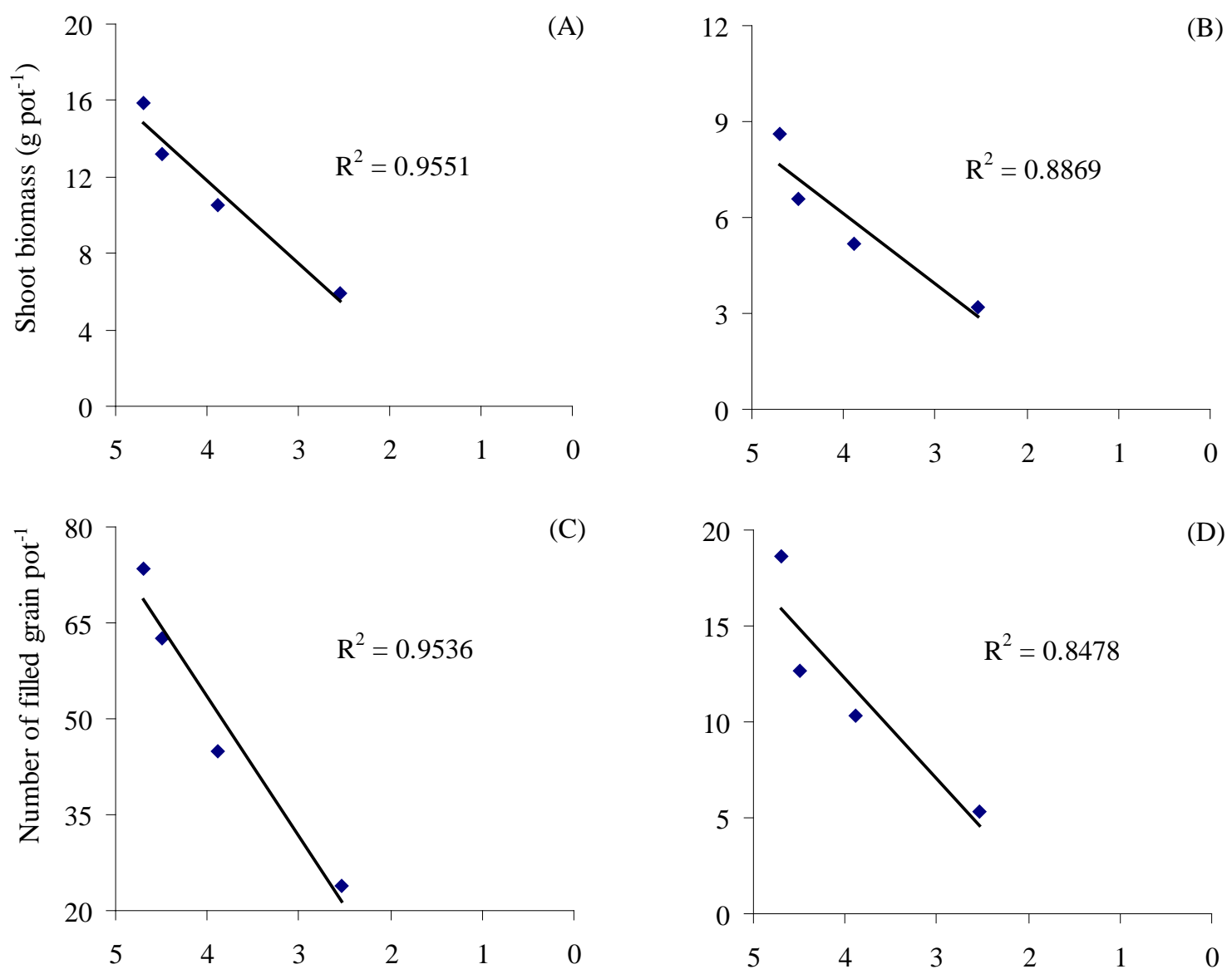

Total chlorophyll (Chl-a + Chl-b) content in leaf $\left(\mathrm{mg} \mathrm{g}^{-1}\right)$

Fig 4: Correlation between chlorophyll content and growth and yield parameters of rice. Shoot biomass production (A); panicle formation (B); filled grain formation (C) and total grain production (D). Chlorophyll content refers to the total concentration of chlorophyll-a and chlorophyll-b. Growth and yield parameters refer to the average value of five rice varieties. 